\title{
De la guerra a la paz. Análisis dialéctico del proceso histórico salvadoreño*
}

\author{
RICARDO RIBERA
}

\section{Historia de la guerra}

El árbol procede de la semilla. Pero desde la semilla no se explica el árbol. Éste no se "deduce" de aquélla. Al revés. Es desde el árbol que podremos entender la semilla. Es únicamente desde el final del proceso que vamos a poder comprender su inicio y las etapas que lo componen. Planta, flor, fruto y semilla, aparecen desde el conjunto del proceso en una secuencia lógica y determinada internamente. Son fases de un único movimiento dialéctico. Se explican una a la otra, una vez se ha comprendido a lo que apuntaban.

Bellas imágenes que proceden de un filósofo de la historia, generalmente oscuro y difícil de entender, como es Hegel. Capaz también de expresarse con claridad y expresividad, a través de ejemplos e imágenes, como las aquí citadas. Al llegar a un punto de culminación

* Todos los materiales han sido publicados en el periódico virtual EL FARO (www.elfaro.net) en la sección especial titulada De la guerra a la paz. Además este material ha sido utilizado por su autor en el curso libre "El método dialéctico de análisis y el proceso histórico salvadoreño", del 4 de Mayo al 29 de junio de 2002. El autor es historiador y catedrático del Departamento de Filosofía de la UCA, San Salvador. 
podremos establecer una periodización adecuada, que se corresponda con lo que el proceso "ha sido", con lo que aparece como su esencia y su lógica fundamental. También inversamente. Si falta una periodización, se escapa parte esencial de la comprensión a cabalidad del proceso histórico.

El investigador, al establecer los períodos debe partir de la objetividad de los hechos. Pero no podrá eludir lo subjetivo. Porque la periodización depende de la interpretación global que aquél haga y de la perspectiva con que examine los diversos acontecimientos. De modo que una periodización, aun siendo muy objetiva, nunca será única. En el caso del conflicto salvadoreño, por ejemplo, diferirá si el enfoque se hace desde la óptica de los años ochenta, de lo que estaba ocurriendo durante la guerra civil, o si desde la perspectiva de la década siguiente, desde la perspectiva de lo que fue su resultado. Se desprenden entonces dos periodizaciones diferentes y complementarias. La primera se refiere a una historia de la guerra mientras la segunda ofrece la historia de la paz. El proceso fue ambas cosas a la vez. Por eso no hay contradicción - o mejor dicho, sí la hay, pero en lógica dialéctica- entre las dos periodizaciones del mismo proceso histórico salvadoreño.

Ya sabemos - hoy lo sabemos, no a mitad del proceso- que la guerra civil salvadoreña culminó con la solución política negociada. El conflicto terminó, aparentemente, en enero de 1992 con la firma de los acuerdos de paz. Habrá que examinar críticamente esa afirmación. Pero lo que sí queda establecido es que el resultado de la guerra fue la paz. Por lo cual no forzamos la objetividad de los hechos al proponer el método dialéctico de análisis, dado que nuestro proceso cumple cabalmente el modelo teórico: cada cosa genera su contrario, el cual brota de dicha oposición.

En este caso, lo que la guerra engendró fue su contrario dialéctico, es decir, la no-guerra, la paz. También la guerra había surgido de su opuesto, de la paz de los años setenta. Pero ésta presenta su carácter falso, pues incuba el conflicto por venir, siendo la guerra de los ochenta la negación de la paz de la década anterior. La paz actual cobra así la dimensión de negación de la negación: niega la guerra que había a su vez negado la paz de la dictadura. El tiempo actual no es el retorno al pasado, a una situación de paz preexistente, sino que se trata de una paz diferente, superadora, sobre fundamentos distintos, a la que la 
nación no habría llegado si se hubiera "ahorrado" su difícil gestación y doloroso parto.

La guerra arranca del período anterior, en el cual "todavía" no hay contienda bélica. Pero sí acumulación de hechos de violencia política. Hasta que la cantidad se vuelve calidad, el cambio cuantitativo transformado en cualitativo. Difícil es precisar una fecha. La espiral violenta se acelera desde el fraude electoral de 1977. Tiene un claro repunte en 1979 y resulta ya innegable su dimensión de confrontación militar a partir del golpe de estado de octubre de este mismo año.

La ONU prefirió adoptar el año calendario - desde el $1^{\circ}$ de enero de 1980- al fijar qué período debía cubrir la Comisión de la Verdad para esclarecer los "graves hechos violatorios de los derechos humanos" acontecidos durante la guerra. No adoptó el 10 de enero de 1981, inicio de la "ofensiva final" del FMLN, por dos razones básicas. La primera, para poder incluir en la investigación el asesinato de Monseñor Romero, uno de los crímenes más connotados del conflicto. Y para no achacar sólo a la insurgencia la responsabilidad de haber empezado el conflicto. Pues en 1980 el FMLN ni siquiera había sido fundado. Tampoco resulta absuelto. Los grupos guerrilleros habían acrecentado su accionar en ese tiempo. Por otra parte, tampoco el ejército había asumido en esas fechas todo el protagonismo que tomará después.

En eso consiste justamente la esencia del primer período de la guerra civil salvadoreña: en su carácter irregular. Uno y otro bando están ya configurados, pero no formalmente, y lo que predomina es la informalidad. En el gubernamental son los cuerpos de seguridad y las redes de escuadrones de la muerte quienes llevan el peso principal de la reacción represiva. Predomina la descentralización y la coordinación es escasa. La Guardia no comparte su información con la Policía de Hacienda, ni la Policía Nacional con aquéllas. En cada uno de estos cuerpos se organizan escuadrones de la muerte al margen de la jerarquía formal. Después se sabrá que la Unión Guerrera Blanca, UGB, operaba desde la GN, el Ejército Secreto Anticomunista, ESA, en el cuartel de la PH y la Brigada Maximiliano Hernández Martínez procedía de las instalaciones de la PN. La Fuerza Armada estaba al margen y no controlaba la acción represiva, al estilo "guerra sucia", la que era protagonizada por estas otras instancias. En contadas ocasiones fue requerida para intervenir en las acciones de represión directa. 
También del lado insurgente el accionar era descoordinado y descentralizado. Cada una de las cinco estructuras tenía sus propios planes operativos y dejaba en gran libertad de acción y de iniciativa a sus células guerrilleras y comandos urbanos. Parte del éxito se centraba en esas características de secretividad y clandestinidad con que ambos bandos se combatían. Mucha actividad tenía fines propagandísticos. Y el blanco podía ser cualquiera identificado como del bando enemigo. La violencia se iba imponiendo como la forma privilegiada de hacer política. Triunfaba la tendencia hacia la militarización de la política.

Este primer período de guerra irregular queda superado al conformarse el FMLN como reunión de las organizaciones guerrilleras, que aspiran ahora en constituirse como ejército revolucionario. Adoptarán la estructura de un ejército, con su Estado Mayor, planes centralizados, logística, columnas, batallones y brigadas. Del bando gubernamental la Fuerza Armada pasa a hacerse cargo del conflicto, subordinando a su mando los cuerpos de seguridad, disolviendo aquellas estructuras de escuadrones o absorbiéndolas en una única. A partir del 10 de enero de 1981 ya son claramente dos ejércitos los que se están enfrentando. Se ha entrado en un nuevo período. Es el vuelco a la guerra regular, planificada centralmente, jerarquizada. Se supera la anarquía de antes y se racionaliza el esfuerzo militar.

Se ha entrado al segundo período, que denominamos de guerra total. En ésta lo esencial es buscar la derrota militar del enemigo. Se espera alcanzarla al corto plazo. El ejército monta grandes operativos del tipo "yunque y martillo" para acorralar y aniquilar las fuerzas del FMLN. Éste aplica una estrategia para "resistir, desarrollarse y avanzar". Aspira a desencadenar una ofensiva que arrastrase a la población a una insurrección triunfante. También predomina del lado insurgente la búsqueda del aniquilamiento de su enemigo. De hecho algunos puestos de la Guardia, varias patrullas cantonales y ciertos destacamentos militares son arrasados al atacar "lo poco con lo mucho". A los grandes operativos del ejército le opone la táctica de responder "lo mucho con lo poco". Las experiencias vietnamitas parecieran dar frutos en la batalla salvadoreña y el ejército, desmoralizado ante un enemigo que suele rehuir el combate, para sorprender después con golpes fulminantes en la retaguardia, parece cada vez más cerca de un colapso. Corre el año 1983. 
Pero también Estados Unidos conoció la guerra de Vietnam y ha extraído sus propias lecciones. A fines del año impone una reestructuración del ejército salvadoreño: la modalidad de guerra debe adaptarse al tipo de enemigo. Se retorna al esquema de guerra irregular, impulsado ahora por el bando gubernamental, que dota a su ejército de los "batallones de cazadores". Son mucho más livianos que los de "reacción inmediata" - fuerza de choque creada en la etapa anterior- y su misión es sólo patrullar incesantemente las zonas de expansión de la guerrilla. Ya no es el objetivo inmediato la destrucción del FMLN, sino su aislamiento: geográfico, pero ante todo, social. Es la táctica de "quitarle agua al pez".

Obedece a una nueva concepción estratégica: la de "guerra de baja intensidad". Según ella el componente militar ha de ser únicamente un $10 \%$ mientras el político supone el $90 \%$. El objetivo a corto plazo es "ganar la mente y los corazones de la población civil". Especialmente en las regiones donde está en disputa el control del terreno. Donde el dominio de la guerrilla es absoluto toda la población se considera base social del Frente y se aplican tácticas de "tierra arrasada", bombardeos masivos, destrucción de cosechas, etc. Es la idea de desgastar al enemigo antes de pensar en la victoria sobre él. El FMLN se verá forzado a responder de manera similar, impulsando su propia “guerra de desgaste”. Ésta se alarga necesariamente. La victoria se mira al largo plazo.

Descifrada la esencia del plan norteamericano el Frente se apresta a no dejarse acorralar en sus zonas controladas y abandona el esquema de "poder popular" y de doble poder. Se lanza ahora a "extender la guerra a todo el país", volver imposible la afirmación duartista de que "podemos convivir con la guerra" y ganar la normalidad en las ciudades. Ahora la guerrilla retorna a las estructuras de comandos urbanos. Se fija como prioridad derrotar los esfuerzos por reactivar la economía del país y hace del sabotaje un arma estratégica. Es la concepción de "la guerra de las pulgas": no matan al elefante, pero pueden volverlo loco y ponerlo en retirada.

Se ha entrado al período más decisivo: es la guerra integral que durará desde 1984 hasta fines de 1989. En él se abre el diálogo, como otro esfuerzo más para ganar la guerra, y muchos otras iniciativas en diversos escenarios: social, económico, político y diplomático. Con 
menor cantidad de víctimas civiles, la guerra en realidad no se ha moderado, al revés, ha ganado en intensidad y es más integral. Se ha entendido la concepción de que la misma es un fenómeno político. Se pasa consecuentemente a una guerra política. La anterior militarización de la política se ha transformado dialécticamente en la politización de lo militar, es la guerra misma la que se politiza.

La guerra de desgaste provoca, con su alargamiento fatal, el desgaste de la guerra. Ello explica que la culminación de esta etapa, la ofensiva "hasta el tope", noviembre de 1989, encuentre a la población con gran "cansancio de la guerra". Predomina la oposición a ambos bandos y el deseo de paz. Determina el fracaso de la insurrección. También el éxito de un proceso de negociación. En un inicio intentado como otra forma de fortalecerse para la ansiada victoria, pronto el proceso irá mostrando en ese cuarto período de guerra con negociación que sólo es concebible como la alternativa a la guerra. Ésta sigue en el terreno militar, a lo largo de 1990 y 1991, pero va imponiéndose como determinante la mesa de negociación sobre el campo de batalla. La lógica de la politización de la guerra conduce a sus protagonistas a una solución política a la misma, que no contradice sus ideales y propósitos sino que, para su propia sorpresa, los viene a confirmar. Se llega así a la formulación del Acuerdo de Paz, concebido como desenlace "sin vencedores ni vencidos".

Pero el 16 de enero de 1992 no señala el final histórico de la guerra. Faltaba ver que los acuerdos se cumplieran. Y la resolución del problema de dos ejércitos en un mismo país.

La posguerra debe por ello considerarse como parte de la guerra, es su último período. El incumplimiento podría aún derivar en un retorno a la confrontación militar. Termina el primer año de posguerra, 1992, con el desarme del FMLN y la disolución de los batallones elite gubernamentales y dos de los tres cuerpos de policía. También la inscripción formal y legalización del Frente como partido político. No será sino hasta las elecciones de 1994, con su participación electoral en las mismas, que culmina el proceso de paz, según el concepto definido por Naciones Unidas. Y con ello la guerra en su último período, la posguerra. Ésta se constituye a su vez en la primera etapa de la transición democrática. 
La política ha triunfado finalmente sobre lo bélico. Merced a la propia guerra. Antes la política era mero ejercicio del poder. Y éste, pura administración de la violencia. Generó su superación mediante una violencia más exacerbada, el conflicto civil, que pretendía redefinir la cuestión del poder. Ahora la política es concebida como administración de las diferencias, como ejercicio del disenso y el consenso, como competencia en torno a un poder que en alguna medida es siempre poder compartido y responsabilidad conjunta. Si en la dictadura lo central era la confrontación de intereses y de proyectos, en la actual democracia en construcción pasa a ser la concertación de proyectos e intereses la esencia del nuevo tiempo. Todo eso requiere fuerza, pero mucho más precisa de sutileza y conocimiento. En la nueva concepción la política es percibida como un arte y como una técnica.

El viejo ejercicio griego de la política: construir apoyos y lograr convencer, incluso al adversario - ya no vencer al enemigo -, un oficio que en gran medida resulta novedoso, en un país con un pasado pleno de violencia, autoritarismo e imposición. Y por ello mismo, con un futuro más lleno de incertidumbres que de certezas. Al país le pesa su historia. Tal vez por eso procura desconocerla. El olvido puede ser, sin embargo, la forma más segura de perder el rumbo de la historia, ésa que entre todos venimos haciendo día a día.

\section{El golpe del 15 de octubre de 1979.}

\section{Un aniversario incómodo.}

El golpe de estado realizado por la Juventud Militar Democrática el 15 de octubre de 1979 puso fin a casi cincuenta años de dictadura militar. Por tanto, una fecha importante en la historia contemporánea salvadoreña. Sorprende que haya sido condenada al olvido. No interesa. Para algunos porque tal vez demasiado se entusiasmaron con las posibilidades de reforma que parecía abrir. Para otros, a los que la sola palabra producía indigestión, porque desde un inicio aborrecieron el golpe y lo que intentaba. A la extrema derecha y a la extrema izquierda el 15 de octubre incomodó. Al centro también, pero más tarde. Al parecer, hoy incomoda a todos. Al menos en eso hay consenso. 
El golpe no evitó la guerra civil. Probablemente ya era tarde para evitarla. Pero lo intentó. Lo cual no es poco mérito para quienes lo protagonizaron. Su mayor lucidez estuvo en los fines que plantearon. No así en los medios. De tal modo fueron débiles en lo táctico que contribuyeron a precipitar al país en el abismo de la guerra civil. Sin quererlo. No obstante, su programa de reformas sería realizado. Pero por otro gobierno y con otra intención.

La proclama de la Juventud Militar Democrática alcanzaría estatuto de realidad en el contenido de los acuerdos de paz, en enero de 1992, sin que se haya reconocido jamás este mérito de anticipación histórica a sus protagonistas. Es justo rendirles tributo por ello. También por la intención patriótica y social que los inspiró. Como valoración humana. La histórica debe ser otra. Ya lo consignó Dante en La Divina Comedia: "el camino al infierno está empedrado de buenas intenciones". Pero no era sencillo en esa coyuntura.

Se vivían días confusos y agitados allá por 1979. Y no era fácil orientarse políticamente cuando tantos acontecimientos hervían en la olla de la historia. El general Romero pretendió endurecer aún más la dictadura en vez de flexibilizarla. Lo único que consiguió fue quebrarla. Su mandato presidencial, inaugurado en 1977 tras un escandaloso fraude electoral, se desgastaba muy rápidamente. Crecía el movimiento opositor y éste se radicalizaba ante la falta de espacios políticos. Los escuadrones de la muerte ensangrentaban el país. Sin acallar las protestas populares. La guerrilla se fortalecía.

“iNicaragua venció, El Salvador vencerá!” Somoza abandonaba el poder en julio de 1979 y la ofensiva sandinista triunfaba en toda línea en el vecino país causando una conmoción en El Salvador. Estados Unidos, preocupado, había presionado a Romero para que concediera una apertura. Respondió con un Foro Nacional, parodia de diálogo donde sólo la derecha participó. La oposición replicó creando su propia instancia de concertación: el Foro Popular. Por primera vez, a los partidos que habían luchado en el plano electoral se sumaban organizaciones populares orientadas en la línea de lucha armada y otras fuerzas sociales, universidades y sindicatos.

Romero resistía cualquier diálogo. Estados Unidos se impacientó. Dio luz verde a un golpe de estado. Los acontecimientos se precipitaron. Eran varios los grupos con preparativos golpistas. A inicios de 
octubre la inteligencia norteamericana desmontó la intentona de golpe ultraderechista que desde el propio Ministerio de Defensa se venía fraguando. Pero no alcanzó a impulsar su propio golpe con los jefes militares que tenía controlados a través de la CIA. Se le adelantaron los jóvenes oficiales que en su rechazo a la corrupción y represión imperantes habían contactado con fuerzas del Foro Popular, a fin de concretar un programa democratizador. Ante los hechos consumados, lo más que consiguió la Embajada fue colocar algunas de sus piezas en el nuevo gobierno resultante. Sería suficiente.

Educados en el respeto a la jerarquía, los jóvenes oficiales que preparaban el golpe buscaron un jefe militar que los respaldara y encabezara. Hallaron en el coronel Adolfo Majano identificación de ideas y lo propusieron para formar parte de la Junta. Una segunda plaza la tenían reservada para su propio líder, el mayor Guerra y Guerra. Pero había varios coroneles que se habían sumado al golpe y pedían ese puesto. La Juventud Militar accedió y es así cómo Abdul Gutiérrez entró a la Junta. Enérgico, se impuso fácilmente al poco beligerante Majano y colocó al coronel Guillermo García como Ministro de Defensa. Estados Unidos tendría en ellos dos a sus mejores aliados para no perder el control de la situación.

El resto de la Junta lo componían tres civiles: uno en representación del Foro Popular, Memo Ungo, un segundo por la ANEP, Mario Andino, y como personalidad independiente el entonces rector de la UCA, Román Mayorga. Dicha composición era de alto nivel académico y humano, sin duda. Pero era impolítica. Era innecesario e inútil incluir a un empresario: el sector privado estaba visceralmente contra cualquier programa de reformas. Tampoco había lógica política en promover al rector de una universidad privada, por mucho que el gobierno se inspirase en el Libro Amarillo, diagnóstico hecho por la UCA y que circuló entre la Juventud Militar. El momento requería políticos, no amateurs.

El PDC, ausente de la Junta, resintió la preferencia otorgada al socialdemócrata Ungo. Sería un factor de su posterior deserción. En enero/1980 un pacto en exclusiva del partido con la Fuerza Armada sorprendería a todos. También las organizaciones populares quedaron fuera y casi enseguida iban a denunciar como autogolpe de la dictadura o como maniobra del imperialismo la insurrección del 15 de octubre. 
Al mismo tiempo el régimen derrocado trataba de recomponer sus piezas.

La Junta Revolucionaria de Gobierno nacía en una tenaza. De un lado el hostigamiento de derecha de prácticamente la totalidad del sector empresarial y parte del propio aparato estatal. Del otro, denuncia e intentos insurreccionales de las organizaciones populares influidas o dirigidas por las guerrillas. Al siguiente día del golpe sectores del ejército junto a la Policía de Hacienda disolvían brutalmente la huelga de las fábricas Lido, Arco, Duramás y Apex. Varios muertos y decenas de capturados. La guerrilla de las FPL respondió “ajusticiando" a un jefe militar. El ERP, por su parte, en los dos días posteriores intentaba provocar levantamientos populares en Mejicanos, Cuscatancingo, San Marcos y Bosques del Matazano. No se había instalado aún la Junta y ya estaba cuestionada por represión y violación de los derechos humanos.

Para la izquierda revolucionaria resultaba de vida o muerte impedir que una salida reformista pudiera abrirse paso. Argumentaba que ésta era imposible. Pero lo era porque ella misma le negaba cualquier posibilidad. El curso de la ofensiva revolucionaria victoriosa en Nicaragua resultaba demasiado cerca en el tiempo y en el espacio, para que no influyera en el pensamiento de los líderes salvadoreños. Así se le facilitó a García y Gutiérrez justificar su línea represiva, que clausuraba de hecho el espacio a la proclama de la Juventud Militar y al programa del gobierno del que formaban parte.

Gente que creía en el proyecto, como tal vez lo era Enrique Álvarez Córdova, al frente del MAG y que esperaba impulsar la reforma agraria, se frustraba ante la oposición total de los coroneles Gutiérrez y García. La izquierda moderada, colocada en papel de represora, buscó mejor una alianza estratégica con la izquierda guerrillera. Difícilmente partidos de centro como el socialdemócrata MNR y el social-cristiano PDC podían seguirla en eso que parecía un salto al vacío. El fin histórico de la alianza que representaba la UNO estaba sellado. También la escisión del PDC, que mayoritariamente seguía a Duarte en su anticomunismo y en su preferencia por la aventura de pactar con la Fuerza Armada y Estados Unidos antes que la aventura de aliarse a una guerrilla marxista-leninista y radicalizada hacia la lucha armada. 
Derrotada la genuina vía de la reforma, en gran medida por sus propias contradicciones internas, sólo quedaba la vía de la revolución y la vía de la reacción, como estrategias contrapuestas para dar una salida a la grave crisis nacional. La reforma se vería revitalizada como opción bajo la conducción de Duarte, pero viciada desde su nacimiento por el abrazo del oso que su doble pacto, con el ejército represor y con la imperialista potencia del norte, le imponía. Sería ése un esquema de reformas con represión, bajo la batuta de Washington, que le costó al pueblo salvadoreño un auténtico genocidio y el retroceso económico de varias décadas.

Demoraría casi un año la configuración de los protagonistas del drama nacional que se venía: el nacimiento del FMLN el último trimestre de 1980 y en el último de 1981 la fundación de ARENA. Sólo faltaban los actores. Porque el libreto del drama quedaba ya delineado. ¿Fue el golpe del 15 de octubre la gran oportunidad perdida? Difícil es decirlo. La pregunta está enlazada con aquella otra: ifue la guerra civil una guerra inútil? Vivimos el resultado de lo que pasó. Para bien y para mal. También vivimos las consecuencias de lo que no pasó, de lo que no llegó a darse. Para bien o para mal. Sin embargo, algunos se la jugaron. Incluso hay quienes perdieron su vida por intentarlo. Y nos sentimos en deuda con ellos. En su aniversario.

\section{La imposición de las extremas}

El 10 de enero de 1980 se difundió en los medios de prensa nacionales e internacionales una Carta Abierta del Arzobispo de San Salvador, monseñor Óscar Arnulfo Romero, al Presidente de los Estados Unidos, James Carter. El dignatario de la Iglesia Católica salvadoreña le urgía al mandatario estadounidense cesar toda ayuda al régimen ante las masacres y atrocidades que estaban ocurriendo en el país. El documento hacía una fuerte crítica a las autoridades gubernamentales de El Salvador por su complicidad, responsabilidad o incapacidad para detener la creciente represión. Exigía de la potencia norteamericana una firme posición de condena y el corte de toda asistencia de cualquier tipo al gobierno salvadoreño.

No tuvo éxito en su petición. La ayuda estadounidense siguió fluyendo a El Salvador. Al contrario, ésta pronto sería incrementada sustancialmente. La política internacional de la Administración Carter 
de promoción de los derechos humanos tenía un claro filo contra los regímenes del llamado "socialismo real". Pero al mismo tiempo se mostraba hipócritamente tolerante frente violaciones a los mismos en países del autodenominado "mundo libre".

La experiencia nicaragüense - donde la permisividad norteamericana ante la insurrección de los sandinistas, con quienes pactó una transición democrática que fue después irrespetada por ellos, ayudó al colapso del régimen - no iba a repetirse en El Salvador. Era ésta una firme determinación de la Administración Carter. Acosada por las duras críticas de los sectores conservadores ante el naufragio de la política exterior estadounidense en Nicaragua, que fortalecían al candidato presidencial Ronald Reagan, no iba a dejarse ablandar por la demanda de un líder religioso centroamericano. Era ése un año electoral en Estados Unidos. Mal momento para mostrarse blando en momentos en los que un fortalecimiento de las guerrillas marxistas en El Salvador podía significar un nuevo revés estadounidense en el tablero mundial de la guerra fría.

La postura del arzobispo constituía para Estados Unidos un exabrupto incómodo y una preocupante osadía. Lejos de ser vista como lo que era: un último y desesperado intento pacificador, la carta sería considerada como un obstáculo a la propia estrategia "pacificadora" que la potencia estadounidense había diseñado para El Salvador.

A estas alturas nadie niega que el Pacto entre Fuerza Armada y Democracia Cristiana se fraguó en la Embajada norteamericana. Para ésta el Pacto era la clave para revertir la situación de vacío de poder que sobrevenía tras el golpe de estado del 15 de octubre y el colapso de la primera Junta que culminó con la renuncia masiva del gabinete al inicio del año. Estados Unidos presionó a unos y otros, jefes militares y dirigentes del PDC, a fin de hacer viable un instrumento de gobierno capaz de imponer el esquema de reforma con represión que los formuladores de política en Washington habían concebido.

Nada de concesiones a la izquierda revolucionaria ni al movimiento popular que ésta dirigía o influía. Tampoco permitir que la derecha oligárquica se recompusiera y recuperase el poder perdido. La estrategia norteamericana preveía golpear simultáneamente a unos y a otros. Debilitar a la revolución escalando la represión y debilitar a la reac- 
ción mediante una reforma agraria y una nacionalización bancaria que socavara su poder.

La indócil oligarquía salvadoreña, que había resistido anteriores presiones para moderar sus posiciones y permitir reformas estructurales en el país, así como los sectores duros del anterior régimen militar, pasaban a ser vistos como obstáculos por Estados Unidos que decidía tomar cartas en el asunto imponiendo a todos su propia estrategia.

El PDC, por su pasado opositor, sus planteamientos reformistas y su inequívoco anticomunismo, era el instrumento ideal para protagonizar el impulso a las decisivas reformas. Duarte, el antiguo candidato de la UNO derrotado por fraude electoral en 1972, el mejor candidato para encabezar el proyecto.

Pero, por el momento, éste todavía no había recuperado las riendas de su partido, del que había estado alejado casi ocho años por su exilio. Sólo iba a ser cuestión de tiempo lograr que su protegido escalara hasta la Junta y se hiciera con el control de la conducción del partido y del Estado.

En el PDC prevalecían aún otros líderes y otras corrientes, genuinamente reformistas, que confiaban ingenuamente en que su presencia en el gobierno contribuiría a terminar o al menos suavizar la represión. "Sin nosotros sería peor" - era su pobre argumento a la crítica que monseñor Romero formulara.

La perversa lógica histórica en que había entrado la nación pronto demostraría la inviabilidad de esos buenos deseos. El arzobispo era más certero en su diagnóstico político que el análisis que estos profesionales de la política hacian. Cuando vinieron a interponer su renuncia, durante la primera quincena de marzo, era tarde para salvar su proyecto. Justo a tiempo, al menos, para salvar su trayectoria política personal y evitar remordimientos de conciencia.

Pocos días después caía asesinado monseñor Romero. Ellos, para su fortuna, ya no eran parte del gobierno. Se alejarían del país y de la política, o se sumarían al proyecto revolucionario ayudando a crear una instancia, el FDR, que acompañaría al FMLN en el esfuerzo de la guerra de liberación, pero sin tomar las armas ni tener en su conduc-

De lo guerro o lo par. Anóllsis dialóctico del proceso histórico solvadorerio 
ción mayor influencia que la de ser considerados "aliados estratégicos".

Tampoco en la mesa de negociación van a ser tomados en cuenta, lo que fue evidentemente un déficit del proceso. Cooptados por la revolución, eran claro testimonio del fracaso de su opción por la reforma.

Esta bandera sería tomada por Duarte y sus allegados, una vez las tendencias de centro- izquierda dejaron el partido permitiendo la unanimidad del liderazgo. Reformas teñidas en sangre, porque toda su radicalidad se diluía en el marco del genocidio que se estaba efectuando. Reformas que alimentaron una virulenta reacción de la oligarquía afectada y que fueron el detonante para la incorporación masiva de las derechas al nuevo proyecto que el mayor Roberto d'Aubuisson venía tejiendo.

Todavía no existía ARENA en 1980, no siquiera en la mente de su fundador. Pero una vez fracasado el intento paramilitar del FAN se abriría paso la idea de jugar según las reglas de juego que Estados Unidos había impuesto: reconstruir la institucionalidad del Estado, dotarlo de una nueva Constitución y propiciar el mecanismo eleccionario para el acceso al poder político. Era el precio a pagar para darle rostro "democrático" al régimen surgido del golpe de estado. También para quitarle base social y desgastar al proyecto revolucionario.

De tal manera que a la altura del primer trimestre de 1980 todavía no estaba unificada la extrema derecha, así como tampoco lo estaba la extrema izquierda. El primero de los tres polos ideológicos se había ya adelantado a configurarse, el que pretendería estar contra ambas extremas.

Se trataba del proyecto duartista pro-norteamericano, en realidad una "extrema centro". Asentada precariamente en el poder desde marzo de 1980, su verdadera oportunidad la tendría durante el período presidencial de Napoleón Duarte, entre 1984 y 1989.

Pero ésa es ya otra historia. La que quedaba presagiada en este decisivo primer trimestre del año 1980. Entre el momento de la Carta Abierta al Presidente Carter y el de la muerte de monseñor Romero. Con él se enterraba la moderación. Había sido asesinada. 


\section{Los años terribles}

El 24 de marzo de 1980 caía asesinado Óscar Arnulfo Romero, Arzobispo de San Salvador. Un día antes, en su homilía dominical, había hecho un dramático llamamiento a los soldados y guardias nacionales a no seguir derramando la sangre de sus compatriotas. Les recordó que por encima de las órdenes de los hombres estaban las leyes de Dios y que Él ordenaba "no matarás". Prácticamente un llamado a la insubordinación. "En el nombre de Dios y en el nombre de este sufrido pueblo, cuyos lamentos suben cada vez más tumultuosos hasta el cielo, les pido, les ruego, les ordeno, en el nombre de Dios, cesen la represión."

El magnicidio, ejecutado con toda frialdad por un tirador profesional durante la misa, en el momento que la víctima levantaba los brazos para la consagración, conmocionó en grado sumo al pueblo salvadoreño y a la opinión pública internacional. No era para menos. Hacía siglos que en la Iglesia Católica no se producía el martirio de un obispo.

Nadie reivindicó el asesinato. No hacía falta. Tampoco hubo exposición de motivos o propósitos. Pero el mensaje era inequívoco: si son capaces de matar a un obispo, es que están dispuestos a matar a cualquiera. La acción cabía plenamente en la definición de terrorismo: víctima inocente, objetivos políticos, buscaba paralizar y aterrorizar.

También es posible que ocultara un cálculo: provocar una insurrección prematura o una guerra civil que permitiera convertir $\mathrm{El}$ Salvador en "la tumba de los rojos". Y también de sacerdotes y monjas que no comulgaran con la política despiadadamente anticomunista de la extrema derecha. El atentado contra el obispo no era sino el punto álgido de una feroz campaña contra la Iglesia popular que ya había cobrado la vida de varios religiosos.

La indignación de la gente era tanta que participó de forma masiva en el funeral del siguiente domingo, 30 de marzo, a pesar de los rumores de que se preparaba una carnicería. Y efectivamente la muchedumbre fue atacada arteramente, también esta vez a mitad de la misa de cuerpo presente, en la Plaza Cívica frente a Catedral.

Las semanas siguientes se vivió en El Salvador una situación casi insurreccional. Con la muerte de Monseñor Romero se desató la guerra. Se había vuelto inevitable. 
No se dio insurrección porque la izquierda revolucionaria no se sentía preparada para encabezarla. Necesitaba tiempo. Era la izquierda en este momento suficientemente fuerte como para impedir un levantamiento espontáneo. Pero, al mismo tiempo, demasiado débil para organizarlo.

También, todo hay que decirlo, demasiado conservadora. Si Lenin hubiera esperado a tener todo listo - unidad, armas y organización la oportunidad insurreccional que se abrió en Rusia en octubre de 1917 se habría perdido. A pesar de considerarse "leninistas", los dirigentes de la revolución salvadoreña demostraron estar a años luz de la audacia y olfato político del viejo zorro bolchevique. Faltaron a la cita histórica. Cuando el pueblo estaba dispuesto y demandaba un levantamiento. Demorarían casi un año en tener todo a punto. Para entonces, tras más de veinte mil muertos, el pueblo era incapaz de seguir su llamado a la insurrección.

La izquierda dedicó el año 1980 a desarrollar su proceso de unificación y a preparar el salto de comandos guerrilleros a ejército revolucionario. Su reciente pasado de confrontación ideológica, sectarismo y rivalidad, era un pesado lastre del que no le resultaba fácil desprenderse. Las organizaciones de masas se unieron sin mucho problema ya en enero en la Coordinadora Revolucionaria de Masas, CRM, que realizó la inmensa manifestación opositora del 22 de enero. Según fuentes internacionales, entre 250 mil y 300 mil personas se congregaron ese día bajo la bandera unitaria contra el régimen represivo. Pero unificar a los partidos que dirigían desde la clandestinidad al movimiento popular era mucho más complejo.

Hasta mayo no se agregaría el ERP a la coordinación que habían iniciado a fines de 1979 las FPL, RN y PCS. Nacía así la Dirección Revolucionaria Unificada, DRU. Había sido preciso vencer el veto interpuesto por la RN contra quienes consideraba "los asesinos de Roque Dalton".

Faltaba aún el PRTC, cuya estructura a nivel centroamericano impedía su admisión en una instancia unitaria que se concebía a sí misma "para la liberación nacional". No sería sino hasta el 10 de octubre de 1980 que se anunciaba la fundación del FMLN, aunque realmente el PRTC no fue integrado antes de diciembre del mismo año. 
Un largo parto. Que tampoco lograba una verdadera unificación del pensamiento ni de la estrategia, pero al menos generaba una coordinación y una comunicación mínimas, que evitara el riesgo de que luchas por la hegemonía derivaran en un enfrentamiento abierto.

Los reformistas, entretanto, divididos por las exigencias que el momento imponía, se vieron forzados a una definición de sus principios. Una parte priorizaba la fidelidad a sus raíces populares y su repugnancia a ser cómplices de la represión contra el pueblo. Mantendría su alianza con las fuerzas de la revolución aunque sin involucrarse en la lucha armada. Y quedarían a merced del hegemonismo de sus aliados, que raramente los consultaban en sus decisiones. Sin embargo, cumplirían un importante y estratégico papel en la escena internacional, integrándose a las tareas diplomáticas y en la elaboración e impulso de las iniciativas de diálogo.

A partir de la renuncia de Rubén Zamora y otros dirigentes demócrata cristianos del gabinete se fundó el Movimiento Popular Social Cristiano, MPSC, y se dio el reencuentro de éstos con los socialdemócratas del MNR, dando impulso a un efímero Frente Democrático, FD. El mes siguiente éste se fundía con la CRM para dar nacimiento al FDR, Frente Democrático Revolucionario, que acompañaría al FMLN en el proceso de guerra de liberación hasta su retorno al país a fines de 1987 y la fundación de la electoral Convergencia Democrática.

Su pérdida de protagonismo y de presencia en la realidad política nacional fue tal que ni siquiera serían tomados en cuenta al abrirse la mesa de negociación, pese haber sido primeros impulsores, los más convencidos de una salida política negociada al conflicto.

Su mayor éxito en ese terreno se daría en junio de 1981 con la conocida como "declaración franco-mexicana". Los gobiernos de Francia y México declaraban la capacidad de negociación de los Frentes, que éstos constituían fuerzas políticas representativas (y no bandas irregulares sin una dirigencia capaz de cumplir y hacer cumplir los acuerdos a que se llegase) y que debía apoyarse una solución política negociada al conflicto salvadoreño, que a estas alturas ya había cobrado unas 30 mil víctimas. Un planteamiento que se oponía directamente al de Estados Unidos, de impulsar las elecciones como alternativa al diálogo-negociación. 
La otra parte de los reformistas, amarrados a la estrategia estadounidense, perdían asimismo mucha autonomía. Con Duarte, consideraban prioritario desarrollar su programa histórico de reformas estructurales, para quebrar el poder de la oligarquía reaccionaria y al mismo tiempo debilitar la opción revolucionaria. Justificaban el genocidio aduciendo su falta de control de los escuadrones de la muerte y de los mandos militares implicados y se proclamaban acosados "por las dos extremas". De la estrategia de "reformas con represión" asumían la primera parte y se constituían en una "fachada democrática" de la segunda.

Las reformas fueron eficazmente ejecutadas en la segunda mitad de marzo, después de la renuncia de Héctor Dada Hirezi a la Junta y su sustitución por Duarte, así como de la salida de Rubén Zamora y su grupo. Una profunda reforma agraria, acompañada por la nacionalización de la banca y del comercio exterior, pretendía dejar sin banderas políticas a los alzados en armas. Pero el precio a pagar era alto: su doble pacto con la represiva Fuerza Armada y con Estados Unidos, la potencia imperialista.

Consecuencia directa de las reformas estructurales fue la súbita politización y movilización de los sectores de poder directamente afectados. La reacción resultó potenciada por la reforma, en mayor medida incluso que por el peligro de la revolución. Varias iniciativas surgidas de la empresa privada se movilizaron en su contra. La Cruzada Pro $\mathrm{Paz}$ y Trabajo fue la que más perduró, aunque no fue la única. Desde instancias como la Cámara de Comercio, ASI y ANEP se conformó la Alianza Productiva como avivadora de una conciencia de clase antes dormida.

En este caldo de cultivo se dio el nacimiento en mayo de 1980 del FAN, Frente Amplio Nacional, estructura semi-clandestina y con vocación paramilitar encabezada por el ex-mayor de inteligencia de la Guardia Nacional, Roberto d'Aubuisson. Considerado como un líder por las asustadas élites del país, su popularidad entre ellas se extendía con cada nuevo vídeo amenazante que hacía llegar desde la vecina Guatemala a los canales televisivos.

En ese tiempo Estados Unidos lo acusó públicamente de ser el autor intelectual del asesinato de Monseñor Romero y le privó de su visa norteamericana. Sus seguidores no se dejaron amedrentar y 
sometieron a severo acoso al propio embajador estadounidense en San Salvador, Robert White. Pero la potencia norteamericana terminaría imponiendo sus reglas y sus criterios a la extrema derecha.

La situación de gobernar por decreto, surgida desde el golpe de estado del 15 de octubre, debía ser superada. Por vía electoral había que dotar al país de una nueva Constitución y de legítimas autoridades. Además, las elecciones eran la mejor fórmula para restar legitimidad a la negociación y para afianzar la propia.

En 1981 empieza la confluencia de las derechas para dotarse de un instrumento que permitiera jugar según las reglas que dictaba Estados Unidos. Un partido como la Alianza de todas ellas y que por la vía electoral recuperase el poder perdido. En septiembre nacía ARENA. La reacción iba a seguir la batalla, pero renunciando a la ilegalidad y la violencia política. Nacía todo un fenómeno social y político.

\section{Elecciones contra negociación}

Puesto un punto final al régimen político salvadoreño - el de la dictadura militar que se había mantenido por casi cinco décadas- el golpe del 15 de octubre de 1979 también había roto con la institucionalidad del Estado. Se debilitaba con ello la legitimidad en el ejercicio del poder. Las sucesivas Juntas Revolucionarias de Gobierno gobernaban por decreto. $\mathrm{Y}$ los alzados en armas aprovechaban esa debilidad para legitimar sus propuestas de diálogo y negociación que acompañaban su esfuerzo militar por derribar un gobierno al que acusaban de genocida. Estados Unidos comprendió que se necesitaba diseñar una política capaz de contrarrestar y ser alternativa a las ofertas negociadoras del bando insurgente.

La política de elecciones y democratización pasó a ser la vía para recuperar la institucionalidad y legitimación del Estado. Al mismo tiempo se constituía en la política gubernamental a oponer a la política de los Frentes de diálogo-negociación. El llamado a elecciones, en lugar y en contra de la negociación. El proceso bélico abría este segundo escenario, en la esfera política y diplomática, para acompañar el esfuerzo de guerra. Eran las políticas de guerra de cada bando, diseñadas como un medio más para coadyuvar a un fin indiscutido en ambas partes en conflicto: ganar militarmente la guerra. 
El proceso histórico desarrollaría su propia evolución en este plano de la lucha. La relación dialéctica establecida entre ambas políticas, la de diálogo-negociación y la de elecciones-democratización, que inició con la oposición máxima, con la mutua exclusión una de otra. Se vislumbraba que el proceso salvadoreño debería tomar uno u otro camino, que eran dos vías excluyentes una de la otra.

Pero un momento posterior las combinó: se abrió el diálogo cuando justamente la vía de las elecciones se había asimismo reforzado. Al final como ya todos sabemos se impuso la solución negociada. Pero ésta incluía la democratización y la organización de elecciones. La exclusión había quedado superada y se daba la fusión de ambas políticas, su reconciliación mutua. Efectivamente, el proceso de paz culminaría con las elecciones de 1994, las primeras realmente democráticas en la historia nacional - con participación de todas las fuerzas políticas, incluidas las que fueron insurgentes- garantizadas internacionalmente.

En la posguerra era aceptado por todos que la paz requería la democracia. Si la negociación se había impuesto como la vía para resolver la guerra, la democratización real aparecía como el único camino para resolver el problema de crisis del régimen político que abocó al país al conflicto. El paréntesis de doce años de guerra se cerraba fundando las bases para la democracia, para hacer que la paz pudiera ser estable y duradera.

Negociación y democratización aparecían ahora como las dos caras de una misma moneda. Los acuerdos de paz como el resultado de un proceso de acumulación, en el marco del doloroso parto de la guerra, tanto en el terreno del diálogo y la negociación, como en la esfera electoral y de democratización. Ambos bandos habían contribuido, aunque a menudo inconscientemente, a su acumulación respectiva y podían con satisfacción contemplar en los acuerdos finales el fruto de su propia contribución al proceso histórico.

Esta perspectiva resulta indispensable a la hora de revisar el significado de los hechos históricos durante los ochenta. Los avances en uno y otro terreno, como parte de una lógica del proceso que se va imponiendo y que frecuentemente resulta opaca para sus propios protagonistas. Tal como reflexionaba Hegel, cierto grado de ignorancia es imprescindible para que la historia se realice: "Si los hombres lo 
supieran todo, no harían nada". Nuestra guerra civil generó un desenlace no previsto, no deseado durante largo tiempo, por sus actores. $\mathrm{El}$ proceso presenta una lógica que se hace transparente al cerrarse el círculo con el que concluye el período.

Presionada y convencida por la potencia estadounidense, la ultraderecha acepta desmontar sus estructuras paramilitares y escuadroneras, para reorganizarse como partido electoral. Surge así ARENA, a fines de septiembre de 1981, con el fin de estar presente a la cita electoral de 1982. Será ésa la vía para dotar al país de una nueva Constitución y de superar la jefatura colegiada que suponían las Juntas Revolucionarias de Gobierno.

Las elecciones dan un resultado paradójico: el PDC, favorito de Estados Unidos, es el partido con mayor cantidad de votos, pero lo superan los diputados conjuntos de PCN y ARENA. Ésta exige llevar al Mayor d'Aubuisson a la Presidencia de la República. El imperio considera, con razón, que la imagen gubernamental, lejos de mejorar, se va a deteriorar aún más si el acusado públicamente de ser responsable por el asesinato del obispo mártir asciende a Presidente. La democratización empezaba con mal pie: para que fuera exitosa era imperativo irrespetar los resultados.

Es así cómo, a propuesta de la Fuerza Armada, se instaló al Dr. Álvaro Magaña en la Presidencia. A d'Aubuisson se le ofreció presidir la Asamblea Constituyente. Ésta culminaría su labor en diciembre de 1983, pasando a ser desde ese momento Asamblea Legislativa hasta concluir su mandato en 1985. De tal modo, pudieron encararse las presidenciales de 1984 con una recién estrenada Constitución. Esta vez sí Estados Unidos conseguiría lo que quería: la victoria, por gran margen, de Napoleón Duarte. El PDC repetiría al año siguiente su triunfo electoral, obteniendo mayoría absoluta en el parlamento, con lo que se presagiaba una muy cómoda situación gubernamental, a condición de que la insurgencia fuera mantenida a raya.

El PDC había ya realizado en gran medida su programa de reformas en 1980 y ARENA se había encargado de ponerle candado constitucional a la reforma agraria. Su Fase II, la más decisiva porque debía afectar las fincas cafetaleras más numerosas y productivas, las de tamaño medio, quedaba de hecho fuera de la agenda. Pero Duarte hallaría la forma de dinamizar su período presidencial. 
Prometió en su campaña ser el Presidente de la Paz y sorprendió a todo el mundo al retar a los Frentes a una reunión de diálogo en La Palma. La propuesta, hecha sorpresivamente, más buscaba el rechazo de su contraparte y reforzarse así propagandísticamente. No obstante, la reunión se realizó y fue seguida de una segunda el mes siguiente. Apenas instalada la fase del diálogo ésta se agotaba sin ofrecer frutos concretos. Cada bando quería demostrar la falta de voluntad de su adversario, cediendo en lo mínimo en sus propias posiciones. El diálogo mostraba ser algo muy diferente a la negociación.

Para llegar a ésta la guerra debería primero agotar todas sus potencialidades. Con la democracia cristiana en el gobierno, Estados Unidos se jugó todas sus cartas. La estrategia "de baja intensidad" se implementó a plenitud forzando al FMLN a reconsiderar la suya. Éste retornó a las tácticas irregulares y tuvo éxito en extender sus operaciones a casi todo el país. El conflicto se había convertido en guerra de desgaste.

Pero en su esfuerzo por desgastar al adversario ambos bandos se debilitaban a sí mismos y perjudicaban su apoyo popular. El cansancio de la guerra se extendía entre la población y, con él, el rechazo a los contendientes. La gente se resentía con el gobierno cristiano-demócrata que imponía su esquema de economía de guerra, casi tanto como con la guerrilla que por su parte impulsaba su respuesta de guerra a la economía.

No es de extrañar que en la coyuntura eleccionaria de 1988-1989 se haya dado el desplome electoral del PDC, frente al ascenso incontenible de su principal rival, ARENA. Desde el punto de vista del proceso de democratización constituía un segundo hito: con Duarte había llegado democráticamente al poder el primer civil en medio siglo, con el gane de Cristiani se daba ahora el recambio pacífico en el gobierno, ascendía la oposición y el "partido oficial" reconocía el resultado y los cuarteles permanecían tranquilos y sin inquietudes golpistas.

Visto superficialmente podría pensarse que llegaba el partido más contrario a la solución negociada. Sin embargo, por ser éste justamente el que representaba al poder económico, y no haber fuerza política más a su derecha, era en verdad la única que podía abrir la verdadera negociación. 
La historia le haría un guiño irónico a todos los actores, demostrando su fuerza de imposición, cuando forzó que el partido que había nacido gritando "negociación es traición" se viera arrastrado a instalarla, tras los acontecimientos de la ofensiva del 89 y la muerte de los jesuitas. Al final sería Alfredo Cristiani quien recibiera el título de "Presidente de la Paz", inconcebible un tiempo atrás, pero determinado por la madurez del proceso.

Tampoco el perfil de los acuerdos de paz en su perspectiva electoral, de legalización y de desarme, podía ser previsto ni hubiera sido aceptado a mediados de la década por el FMLN y sin embargo será aceptado en el transcurso del desarrollo de la negociación. No sin forzar profundos cambios políticos e ideológicos en su dirigencia.

De manera que tanto ARENA como el FMLN son profundamente transformados, la historia los ha moldeado. "Es verdad que la historia la hacen los hombres -advertía Hegel_, pero no es menos cierto que ella hace a los hombres." Las dos fuerzas políticas más inflexibles y más guerreristas, terminaron siendo los paladines de la paz. Los dos partidos más verticalistas y disciplinados, los más autoritarios e ideológicos, impulsaron el proceso de la transición a la democracia.

No sin traumas. Sí con la convicción de no estar traicionando sus orígenes ni sus ideales, sino tratando de estar a la altura de los tiempos y de las exigencias que su pueblo les reclamaba. Ha de ser la base de la reconciliación histórica, ésa que precisa día a día ser reavivada, pese a los roces cotidianos.

El país cuenta hoy con una izquierda y una derecha. Conviven las dos. Y se atacan. Pero en el fondo saben que mutuamente se necesitan. La democracia los necesita. Y todos nosotros.

\section{Presidente de la paz}

José Napoleón Duarte había anunciado que sería el Presidente de la paz. Hizo por serlo. Pero no pudo. La historia le negó incluso el privilegio de iniciar el proceso de negociación. Sólo pudo lanzar una etapa de diálogo. El cual se agotó a sí mismo durante los 5 años de su presidencia. Saltar a la siguiente etapa, a la verdadera negociación, iba a requerir superar y negar la anterior. Negación dialéctica. No por simple acumulación, sino mediante el rechazo a lo que había sido 
esencial durante el diálogo. Por ello mismo, el recambio partidario en el poder vino a facilitar las cosas. ARENA criticaba todo lo que había hecho el PDC en el gobierno, incluida su política de diálogo. La reformulación de tal política, en vez de la simple continuidad, parecía lógica en 1988 y 1989. Pero escondía una lógica más profunda: la que llevaría el proceso a una etapa superior y definitoria. De tal modo, insospechadamente para todo el mundo, incluido su propio protagonista, quien resultó ungido por la historia como Presidente de la $\mathrm{Paz}$ fue Alfredo Cristiani.

Desde un inicio anunció que no iba a desgastarse involucrándose personalmente en las pláticas. Como Presidente de la República tenía otros importantes asuntos que atender. A tal efecto, iba a nombrar una Comisión que tendría poderes para negociar, que le informaría directamente y recibiría de la Presidencia instrucciones pertinentes. Justificaba la evidente disminución del perfil de las rondas de diálogo con el argumento que éstas tenían que dejar de ser un "show" propagandístico y adquirir seriedad. Por ello mismo, exigió que las conversaciones dejaran de darse al interior del país y que tuvieran estricto carácter confidencial. Retó a la insurgencia a demostrar su voluntad de paz aceptando dichas condiciones, las que impedirían sacar "raja política" a cualquiera de las dos partes.

De hecho estas medidas sacaban al proceso de las limitaciones a que la etapa de diálogo lo sometían, pues dejaba de ser la propia legitimación y el desgaste de la del adversario el objetivo central y pasaba a ser la exploración de los contenidos concretos, posibles coincidencias y desavenencias de fondo la nueva razón de ser. El proceso entraba a una fase de pre-negociación. Le faltaban cosas esenciales para ser ya negociación: un mediador con la suficiente capacidad política y poder para presionar, una agenda definida de común acuerdo y, sobre todo, la voluntad inequívoca de las partes de avanzar por esta senda en forma ininterrumpida y hasta lograr acuerdos sustanciales que significasen una salida al conflicto. Por eso el salto a la etapa de negociación no se dio sino tras la gran ofensiva del FMLN. Seguía el empate. Urgía terminar la partida. Y no había tiempo para jugar prórrogas. El final sería a penaltis.

Si se mira superficialmente, la instalación de la mesa negociadora a principics de abril de 1990 en la subsede de la ONU en Ginebra se 
daba paradójicamente en el menos previsible de los momentos cuando la guerra había recrudecido, Estados Unidos acababa de demostrar la determinación de su injerencia en el área al invadir en diciembre Panamá, capturar a su Presidente para ser juzgado por narcotráfico y disolver su Fuerza Armada. Asimismo, después de la inesperada derrota electoral de los sandinistas. La ofensiva de noviembre del FMLN podía ser interpretada como una gran provocación que podía obstaculizar el arranque de la negociación, así como provocadora había sido de la otra parte el asesinato del dirigente de la Comisión de Derechos Humanos o la bomba contra la federación sindical FENASTRAS, que en su momento motivó la ruptura unilateral del diálogo por parte de la insurgencia. El crimen contra los jesuitas marcaba un hito en la brutalidad e inhumanidad del conflicto, que recordaba el nefasto momento del magnicidio en 1980 del arzobispo mártir. Sin embargo, en el nuevo momento de maduración del proceso, todos estos elementos venían a impulsar la negociación como única vía para racionalizar y buscarle punto final al conflicto. Ambas partes tenían tareas pendientes.

Sería imperativo sujetar a las fuerzas más militaristas y radicales, para evitar nuevas provocaciones que dieran al traste con la vía negociadora que ahora se emprendía, bajo la fuerte presión de la comunidad internacional. El FMLN logró la unanimidad sin mayor proble$\mathrm{ma}$, aunque involucrando directamente a la Comandancia General en las etapas más delicadas de la negociación y llevando a la comisión negociadora a diferentes jefes militares que ahí eran ganados por el espíritu pacificador y se apartaban de tentaciones "golpistas" contra la jefatura que negociaba la salida de la guerra.

De parte gubernamental el problema era más delicado. Coincidía el gane eleccionario de ARENA en la coyuntura 1988-1989 con el ascenso a la cúpula del ejército de los miembros de La Tandona. Compañeros de promoción de d'Aubuisson, estos coroneles eran considerados los más duros entre los duros. Todo hacía presagiar una escalada en la guerra en vez de voluntad de pacificación. Le tocaría al Presidente Cristiani lidiar con este problema. Paralela a la negociación con la contraparte se iba a desarrollar otra, igual o más importante, en el seno del bando gubernamental. De hecho, en varios momentos entre 1990 y 1991 hubo rumores golpistas en el seno del ejército. Las páginas de El Diario de Hoy daban cabida a ideólogos de extrema derecha 
que clamaban contra "la traición" a la Patria hecha por el Presidente en las concesiones otorgadas a la insurgencia en el transcurso de la negociación. En realidad, la contradicción entre el gobierno arenero y la cúpula del ejército no era nueva. Expresaba el creciente distanciamiento entre el sector privado y el estamento militar que se fue generando a lo largo del conflicto.

La clase dominante no dejaba de resentir que la Fuerza Armada, en su pacto con el PDC, hubiera respaldado y ayudado a ejecutar la reforma agraria y las nacionalizaciones del comercio exterior y del sistema financiero. Los militares, por su parte, criticaban a los grupos de poder económico el haber sacado del país sus fortunas y resistirse a traer de regreso sus capitales para contribuir a la recuperación económica. "Unos ponemos los muertos, mientras otros ni siquiera su dinero quieren poner", era el reproche habitual entre las filas castrenses. Con el correr del tiempo esta queja era respondida con otra igualmente amarga: "los militares no ganan la guerra porque no quieren, pues no les interesa; han hecho de la guerra un negocio". Ciertamente el grado de corrupción de ciertos jefes militares era obvio y escandaloso. Se enriquecían a costa de las raciones de la tropa, no reportaban los muertos para seguir cobrando por las mismas, a menudo eludían el combate y daban falsas informaciones de sus coordenadas y posición. La guerrilla con frecuencia obtenía armas de algunos jefes militares corruptos. Hubo veces en que a la semana escasa de haber recibido nuevos suministros - fue el caso de los teleobjetivos de rayos infrarrojos para combate nocturno- ya éstos estaban en poder del FMLN: los había comprado a su enemigo.

El hecho es que la desconfianza mutua había llegado a su cenit a fines de la década de los ochenta. Influyó en la selección de Fredy Cristiani como pre-candidato presidencial, en lugar del coronel Sigifredo Ochoa Pérez. El propio d'Aubuisson se inclinó por optar contra su ex-compañero de armas para que un gobierno de ARENA no se viera sometido al dictado del poder militar. En el marco de la guerra los militares eran más poderosos que nunca. Pero al mismo tiempo nunca habían sido más débiles: dependían de la ayuda estadounidense para proseguir la guerra. Y para no perderla. El sólo anuncio de un corte podía generar un colapso.

Optar por Cristiani significaba elegir a un empresario, miembro de la oligarquía económica del país. También era aupar un nuevo pen- 
samiento estratégico, el desarrollado por FUSADES, de la que Cristiani había sido uno de los sus primeros directores. La opción neoliberal se abriría paso con el ascenso del líder empresarial. Y con ello la paulatina unanimidad del sector privado, seducido por su visión de futuro, que aparecía superior a la visión de pasado que representaba la ideología del puro anticomunismo primitivo con que se fundó ARENA.

La historia pondría a prueba esas lealtades. Y también la estatura política de los protagonistas. Alfredo Cristiani supo dar su cuota. El proceso le hizo crecer. Aportó serenidad, no exenta de firmeza. Y soportó las presiones, sin perder imagen. Reconoció al final que la ausencia de democracia había sido la causa de la guerra. Supo estar a la altura del momento. Más allá y a pesar de sí mismo.

\section{El papel de la ONU}

El proceso de negociación terminó a la salvadoreña: a última hora como es habitual entre nosotros. Cinco minutos antes de las doce de la noche del último día de 1991, según relataba Schafik Hándal en una entrevista que fue posteriormente editada como libro. Hay testimonios que lo contradicen afirmando que, en verdad, la mesa negociadora sobrepasó el plazo fatal en unos diez minutos. No es importante. Lo crucial era poder dar a conocer al mundo que dos años de negociación habían concluido satisfactoriamente, que se desactivaba un conflicto que por doce largos años había asolado el país y tenido en vilo a la opinión pública internacional. Júbilo y felicitaciones a los miembros de las dos comisiones negociadoras. Habían sacrificado celebrar las festividades de fin de año con sus familias, a cambio de culminar su trabajo. Lo habían logrado. El paquete de acuerdos quedaba listo. Habían hecho historia.

Alguien estaba particularmente eufórico. Era el Dr. Javier Pérez de Cuéllar, Secretario General de la ONU. Su mandato expiraba y debía entregar su cargo el primero de enero de 1992. Alcanzar la paz en El Salvador había sido uno de sus mayores esfuerzos. Era importante para él culminar dicho proceso antes de retirarse de la conducción del máximo organismo internacional. Y presionó a las partes para que concluyeran la redacción de los acuerdos antes de terminar el año. 
Pero no contaba con la cultura del salvadoreño. Aquí se ama el regateo y se especula con la posibilidad de obtener en el último momento aquello que no se ha podido conseguir previamente. La segunda quincena de diciembre se convirtió así en una guerra de nervios, en el escenario de la sede de Naciones Unidas en Nueva York. Los funcionarios de dicha organización y los diplomáticos de los países coadyuvantes -el "Grupo 4+1", es decir: Venezuela, México, Colombia, España y Estados Unidos- a estas alturas ya estaban exhaustos y preocupados. Había un riesgo de que ante el cambio de Secretario General el proceso fuera a estancarse o retrocediera.

Los negociadores salvadoreños estaban mucho más tranquilos. Todos querían hacer un buen negocio. Conseguir sus objetivos cediendo lo mínimo. Y "bajarse" al otro si era posible. Y que no se lo "bajasen" a uno. Como en el mercado. Pero tanto el que vende como el que compra, ambos saben que hay un interés mutuo tras la discusión que aparentemente los enfrenta: de veras desean los dos hacer la transacción, para eso han llegado y no para perder el tiempo discutiendo. Pero el salvadoreño disfruta todo ese ritual del regateo antes de llegar a un acuerdo final satisfactorio.

A lo largo de la negociación las partes se habían convencido de la necesidad y de la conveniencia de un acuerdo final que los sacara de la guerra, convertida finalmente en una trampa que debilitaba a todos sus protagonistas. El pueblo exigía el fin del conflicto, con lo que el costo de seguir prolongándolo podía ser políticamente fatal para quien apareciera como responsable del fracaso de la mesa de negociación. Por otra parte, la escalada bélica hacía que los dos bandos fueran muy dependientes de la ayuda internacional.

De ahí lo efectivo de la presión que ejercía la ONU sobre ambos. El Secretario General contaba con el mandato del Consejo de Seguridad, reforzado desde mediados de 1991 con un acuerdo bilateral de Estados Unidos y la Unión Soviética. Con ello se lograrían conjurar amenazas golpistas de la Fuerza Armada, así como obtener posiciones más realistas de parte del FMLN. Desde la decisiva ronda de septiembre en Nueva York, cuando se forzó la presencia del Presidente Cristiani y de la Comandancia General del Frente, todos los aspectos sustantivos quedaron delineados y puestos "en el congelador". Como expresó el diplomático peruano Álvaro de Soto, representante del Se- 
cretario General de la ONU y mediador oficial: "no queda acordado nada hasta que no esté todo acordado". Terminada la labor de ingeniería política faltaba el fino trabajo de carpintería: un sinnúmero de detalles y los aspectos no sustantivos de calendario e implementación concreta.

Naciones Unidas fue asumiendo un papel cada vez más clave. Si bien al comienzo del proceso el carácter de su participación había sido definido como de "buenos oficios" fue cualificándose poco a poco. En la ronda de San José, que concluyó con acuerdos sobre derechos humanos y la instalación de ONUSAL, a mediados de 1990, empezó un rol de mediación. Se reunía por aparte con uno y otro bando, planteando sus propias recomendaciones. Pronto pasó a ser mediador activo, presentando a las partes sus propias propuestas, que eran más difíciles de rechazar.

Desde septiembre de 1991 su papel había empezado a ser el de un arbitraje. El árbitro es un juez que decide y puede sancionar. Esa función se esbozó en las etapas finales de la negociación y se concretó en la fase del cumplimiento, cuando se llegó al 30 de octubre de 1992 y no se había ejecutado el calendario. El nuevo Secretario de la ONU, Boutros Boutros Ghali, impuso una nueva calendarización hasta el 15 de diciembre. El gobierno tuvo que cumplir una serie de acuerdos importantes que tenía pendientes y el FMLN culminar su proceso de desarme y desmovilización. El recambio en la conducción de Naciones Unidas no había alterado el compromiso de dicha organización con el proceso.

Así como muchos países metieron sus manos en la guerra, también la paz nacía con los aportes de la comunidad internacional. Solidaridad, que al decir de Gioconda Belli, "es la ternura de los pueblos".

\section{Historia de la paz}

Paralela a la historia de la guerra iba gestándose en el país la historia de la paz. No como algo posterior sino prácticamente simultáneo. La guerra civil lo abarcaba todo a lo largo de los años ochenta. Así aparecía el período. Pero tras esa apariencia se desarrollaba lo que el proceso traía en su entraña y se revelará al final como su verdadera esencia. El conflicto culminó en acuerdos políticos; lo que se estaba 
gestando durante la guerra era la paz. Por tanto, hay que des-cubrir la secuencia del proceso que permite tal desenlace.

Es la historia de la paz, con su propia periodización, con su lógica racional que se impone finalmente sobre la racionalidad bélica. Como contraposición, pero también como fundamento; menos visible pero más decisiva. Oculta al ojo, como las raíces del árbol, que se expanden simétricamente a las ramas superiores sin exponerse a la luz, sino buscando en lo hondo el sustento para el conjunto. El árbol que vemos presupone esas raíces, que alimentan y sostienen, y que crecen en dirección contraria al de la planta.

Habría que decir más bien que ésta se desarrolla en ambas direcciones a la vez, hacia arriba y hacia abajo simultáneamente. De manera similar, nuestro proceso histórico avanza en sentidos contrarios: en dirección a más guerra, - o sea, más intensa, prolongada y sofisticada -, pero también hacia la paz. Es el impulso de la primera el que empuja la segunda.

Los momentos principales que entrañan el salto cualitativo son el diálogo y la negociación. El primero, de naturaleza meramente táctica, lo que de veras pretende es ser un instrumento que ayude a ganar la guerra. Legitimar las propias posiciones deslegitimando las razones del contrario. Minar el apoyo de sus aliados y neutralizar a sus amigos políticos, al tiempo que procura atraerse a los neutrales y conseguir que los amigos se conviertan en aliados. El diálogo es parte esencial de la lucha política y está al servicio del objetivo supremo que sigue siendo la victoria militar. No hay coincidencia entre medio y fin: el medio es político pero el fin está situado en una esfera distinta.

En cambio, en la negociación el medio y el fin coinciden: lo que se busca es una solución política por medios asimismo políticos. Ya no se trata de ganar la guerra sino de "ganar la paz". Ambas partes están ahora conscientes de que para poder tener ganancia tendrán asimismo que ceder. Ya no es vista la guerra como un fin en sí mismo, sino que ha pasado a percibirse como un medio para lograr fines que son de naturaleza política. Si pueden obtenerse por otra vía diferente a la militar, procede abandonar el esfuerzo bélico y ver de avanzar por el camino de la negociación. Concebida ésta al inicio como mal menor, pronto será percibida como una mejor solución que la que podía ofrecer el mero triunfo militar. Transformar el escenario político ha re- 
querido de la transformación de los actores: surge una nueva voluntad política.

Si la voluntad de los protagonistas ha cambiado es porque cambió asimismo su percepción y comprensión del proceso histórico. Éste ha realizado una propedéutica, una pedagogía, educando a sujetos y actores en lo que era y lo que no era posible, en lo que es y no deseable, en cuál es el ideal realista y realizable, y en cuáles pretensiones debían abandonarse por irrealistas y no verificables. En su culminación, los actores políticos conocen mucho más del proceso y también se conocen mejor a sí mismos.

Depuran entonces sus apreciaciones reafirmándose en su razón de ser fundamental, al tiempo que aceptan la reconsideración y modificación de sus tácticas y estrategias, de sus fundamentos doctrinarios, teóricos e ideológicos. En su empeño por transformar el país (lo han logrado aunque según un diseño insospechado y diferente) se han transformado también a sí mismos. La historia de la paz ha incubado a su interior otro nivel del desarrollo histórico: es la historia de la democracia, determinada a iniciarse desde este nivel elemental como lo es la democratización del pensamiento y de la determinación de los actores.

Es así porque el proceso de diálogo y negociación presuponía la concepción programática, donde se exponían objetivos y visión general del problema del poder. En una primera fase de la historia de la paz, previa a la apertura real del diálogo, la que llamaremos fase de pre-diálogo, FDR-FMLN resumían en la Plataforma programática del Gobierno Democrático Revolucionario, GDR, sus concepciones y estrategia fundamental.

Corresponden a una concepción de toma del poder y de victoria total. Aunque, paradójicamente, aparece ese maximalismo en una etapa en la que esa posibilidad está más lejos de ser alcanzable. Los Frentes se reservan el derecho de decidir qué oficiales de la Fuerza Armada podrán permanecer en la institución, recuperada como brazo armado del pueblo desde su propio ejército insurgente, así como las fuerzas políticas autorizadas a seguir funcionando. El respeto a la propiedad privada condicionado también a la conducta que los propietarios y los empresarios concretos hayan tenido durante el conflicto. Se entiende pues que las ofertas de diálogo, además de ser una forma de 
propaganda, se han diseñado como la negociación de la derrota y rendición del bando gubernamental.

Madurado el proceso histórico se abre la fase del diálogo, antes incluso de que el Presidente Duarte lo convoque. Efectivamente, en enero de 1984 los Frentes presentan un nuevo Programa: la propuesta para conformar un Gobierno Provisional de Amplia Participación, GAP.

Presupone que parte del espectro político legal acepte esa base de negociación excluyendo a otra parte - los fascistas, la extrema derecha, los escuadroneros - lo que explica la mayor flexibilidad del planteamiento. El nuevo ejército nacional ya no sería estructurado tomando como eje al FMLN sino como el resultado de la fusión de ambos ejércitos, previamente depurados; el espectro legal de partidos va a abarcar todas las fuerzas democráticas - lo que las define es la aceptación del GAP - excluyendo sólo a las antidemocráticas y militaristas. En realidad, se ofrece acortar la guerra por este procedimiento, antes de su derrota total, y ante las bases propias se presenta como una victoria parcial, antesala de la victoria total a completar posteriormente por medios políticos.

Agotada tempranamente la fase del diálogo, porque la contraparte también ofrece una variante de su propia victoria parcial, queda claro que esta vía del diálogo no avanza si no hay progresos en la correlación militar de fuerzas. Es la guerra la que puede acercar la paz, a condición de que sea superada la situación de equilibrio estratégico o empate militar. La intensificación del esfuerzo bélico se mira como única vía para acercar la posibilidad de la paz. La relación dialéctica entre guerra y paz se hace más transparente.

De ahí que a partir de 1986-1987 se entre a una fase de pre-negociación en la que hay claridad de la impotencia del diálogo, al tiempo que se entiende que falta correlación para forzar la apertura de la negociación. Romper el empate será la meta inmediata, para generar uno de los dos escenarios: o el de un triunfo militar que vuelva innecesaria la negociación, o el de la imposibilidad de tal triunfo - para ambos bandos - que vuelva innecesaria la guerra y por ende posibilite la mesa negociadora. Preparar la contraofensiva estratégica resulta la conclusión lógica y el resto de iniciativas se proyectan como auxiliares de tal estrategia central. 
La valoración de la ofensiva de noviembre de 1989 resulta diferente: lejos de haberse roto el equilibrio estratégico, lo que se ha consolidado es el empate militar. La verdadera negociación se va a fundamentar en esta constatación. No hay vencedor y no va a haberlo. La prolongación de la guerra no conduce a su desenlace. Es imperativa una fórmula que se constituya en alternativa a la misma. La solución negociada no puede ser equivalente al triunfo militar, pero puede ser equiparable: puede ser una variante de la victoria. Siempre que se precisen y redefinan los objetivos esenciales. Los acuerdos deben ser satisfactorios para ambas partes o se corre el riesgo de que la paz sea una simple pausa, preludio a un relanzamiento de la guerra. La negociación pondrá punto final a la misma sólo si se negocia sin trampa y los acuerdos resultan beneficiosos para todos.

Por ello, tan decisivo como la fecha del 16 de enero de 1992, cuyo décimo aniversario celebramos esta semana, será la fase posterior de cumplimiento de los acuerdos. Es la última de la historia de la paz: la pos-negociación, que se corresponde temporalmente con la pos-guerra. Como ella culmina con las elecciones de 1994, fecha clave para la democratización verdadera del país y a partir de la cual el tema de los acuerdos pierde su centralidad en la vida política nacional, independientemente del incumplimiento o retraso en ciertos temas. En ese evento electoral, definido acertadamente por la ONU como culminación del proceso de paz, se entrelazan y combinan las dos políticas de la guerra: la de diálogo-negociación y la de elecciones-democratización. En su reconciliación se expresa la de las partes beligerantes.

Es la dialéctica síntesis de tres décadas consecutivas: la confrontación se ha trocado en su opuesto, la concertación. Pero aquélla sostenía la unificación a derecha e izquierda. Asistimos ahora a la dialéctica inversa: concertan los adversarios y surge la confrontación al interior de cada uno de ellos. Son las claves del tiempo actual, que de nuevo escapan al control de los actores.

Del lado de la izquierda la base de los disensos está en la nueva redefinición programática, la tercera en su historia, que se da a conocer durante la fase de negociación, en octubre de 1990. En la Proclama a la Nación difundida ese mes se expone el concepto "revolución democrática" que sustituye los programas anteriores. Justifica la salida negociada al tiempo que expone el recorte de las aspiraciones in- 
surgentes: han desaparecido las dimensiones anti-oligárquica y antiimperialista de las definiciones programáticas del GDR y del GAP.

Es congruente con el reagrupamiento de fuerzas que la negociación provoca a favor y en contra del proceso. Pero ese realismo político condena al FMLN a integrarse al sistema como un partido más del mismo y promueve que sus límites sean aceptados como el horizonte de lo posible. Automoderación que impulsa su transformación en una izquierda reformista. La revolución como vía y objetivo histórico desaparece del pensamiento aunque se conserve en el lenguaje, sustituida por la reforma.

Ésta muestra su eficacia y viabilidad, tanto en la remodelación de la Constitución como en el alumbramiento de las nuevas instituciones democráticas surgidas de los acuerdos. Abandono de la radicalidad que se refleja en el abandono de que son objeto militantes y bases sociales, ante la nueva prioridad concedida a la competencia electoral y la lucha municipal y parlamentaria.

Divorciada en gran medida de su base social popular, el FMLN ha tendido en la transición a convertirse en el partido de las clases medias urbanas. Nueva izquierda con respecto a la historia política del país, es vieja con respecto a las tradiciones socialdemócratas internacionales.

La ideología no puede así ser cemento de unidad, solamente los intereses políticos. Pero éstos, en su diversidad y particularidad, desunen y confrontan. Lo mismo le ocurre a sus adversarios de la derecha. ARENA pierde cohesión en la medida que aquel cemento ideológico del anticomunismo y la salvación de la patria ya no están sobre el tapete. El neoliberalismo vino a reemplazar y a "modernizar" su ideario y agenda política, abriendo espacio a las confrontaciones internas. Como país y en el marco del proceso histórico más general, los tiempos de revolución (y contrarrevolución) han sido superados y sustituidos por estos tiempos de reforma, la cual amenaza siempre ser desbordada por la revuelta ante la falta de alternativas radicales a los radicales problemas no resueltos. El espectro de la oleada de saqueos y protestas espontáneas en Argentina flotará en nuestro ambiente mientras persista en la clase política la actual tendencia "light", que no corresponde con la dureza de la realidad nacional. 
A diez años de la firma del Acuerdo de Paz la valoración será muy distinta si nuestra mirada se dirige hacia atrás, al camino recorrido y al lugar de donde veníamos, o si se enfoca hacia delante, a lo que nos espera en el inmediato futuro. Hoy por hoy, se advierten más motivos para la preocupación que para congratularnos con la misión cumplida. Como en tiempos de Noé, la paloma de la paz necesita tierra firme, donde posarse y poder buscar ramas de olivo. 